\title{
MICHAŁ SIERBA
}

ORCID: 0000-0002-3237-4635

\section{POMIARA WŁÓCZNA BIELSKA SPORZĄDZONA PRZEZ STANISŁAWA DZIEWAŁTOWSKIEGO SKOCZKA W 1560 R.}

DOI: $10.15290 /$ sp.2021.29.02

\begin{abstract}
Abstrakt. Artykuł omawia kwestię pomiary włócznej przeprowadzonej w Bielsku na Podlasiu w 1560 r. przez Stanisława Dziewiałtowskiego Skoczka. Jego uzupełnieniem jest edycja źródłowa notatki sporządzonej na podstawie rejestru niniejszej pomiary, który nie zachował się w oryginale. Całość stanowi uzupełnienie planu Bielska w 1563 r. wraz z komentarzem, które ukażą się w ramach Atlasu historycznego Polski.
\end{abstract}

Słowa kluczowe: Bielsk Podlaski, pomiara włóczna, Podlasie, małe miasta, epoka wczesnonowożytna

\begin{abstract}
The article discusses the question of the Volok Reform carried out in Bielsk in Podlasie in 1560 by Stanisław Dziewiałtowski Skoczek. It is supplemented by the source edition of the note made on the basis of the register of this reform, which has not been preserved in the original. The whole is a supplement to the plan of Bielsk in 1563, together with a commentary that will be published as part of the Historical Atlas of Poland.
\end{abstract}

Key words: Bielsk Podlaski, the Volok Reform, Podlasie, small towns, early modern era

W drugiej połowie 2021 r. do rąk czytelników zostanie oddany ostatni z tomów Atlasu historycznego Polski będący efektem wysiłków badawczych pracowników Zakładu Atlasu Historycznego w Instytucie Historii im. Tadeusza Manteuffla Polskiej Akademii Nauk i osób z nim związanych ${ }^{1}$. Wspomniany tom będzie dotyczyć województwa podlaskiego w drugiej połowie XVI w. ${ }^{2}$ Wśród

1 Tom został opracowany i zostanie wydany w ramach grantu Narodowego Programu Rozwoju Humanistyki. Tytuł projektu: Atlas historyczny Polski XVI w. - dopetnienie serii; nr projektu: 1aH 15 0373 83; kierownik projektu: dr hab. Marek Słoń.

2 Atlas historyczny Polski. Województwo podlaskie w drugiej połowie XVI w., red. M. Gochna, B. Szady, Warszawa 2021 [w druku] [dalej: AHP]. 
map i planów swoje miejsce znalazł również plan miasta Bielska (dziś Bielska Podlaskiego) z 1563 r. W związku z zasadami przyjętymi w tej serii wydawniczej, plan opatrzony jest również komentarzem ${ }^{3}$. Niniejszy artykuł ma stanowić rozwinięcie wątku pojawiającego się we wspomnianym planie i komentarzu. Celem tekstu jest przybliżenie pomiary włócznej Bielska z 1560 r. i edycja notatki sporządzonej na podstawie rejestru tej pomiary, który nie przetrwał do dziś w oryginale.

Bielsk w czasach I Rzeczypospolitej był miastem położonym w województwie podlaskim w powiecie brańskim. Stanowił stolicę ziemi bielskiej, aczkolwiek w drugiej połowie XVI w. już tylko tytularną, gdyż sąd grodzki odbywał się w Brańsku ${ }^{4}$. W XVI w. był największym ośrodkiem miejskim na terenie województwa ${ }^{5}$. Dziś Bielsk również należy do województwa podlaskiego i jest stolicą powiatu bielskiego ${ }^{6}$.

Osada bielska powstała i rozwijała się początkowo na bagnistym terenie nad rzekami Białą i Lubką, na północy zaś aż do okolic dzisiejszego rynku. Na podstawie badań archeologicznych można stwierdzić, że początki Bielska należy wiązać z osadą, która od X w. funkcjonowała w okolicy dzisiejszej ul. Zamkowej ${ }^{7}$. Niedaleko osady wzniesiono gród nad rzeką Lubką. Pierwsza wzmianka o nim pochodzi z 1252 r. z Kroniki halicko-wołyńskiej. Gród był użytkowany dość krótko, niebawem bowiem spłonął ${ }^{9}$. Na południe od grodu powstało podgrodzie. Na wschód od grodziska po obu stronach dzisiejszej ul. Zamkowej w średniowieczu

3 M. Sierba, Bielsk Podlaski, [w:] AHP.

4 Urzędnicy podlascy XIV-XVIII w. Spisy, oprac. E. Dubas-Urwanowicz, W. Jarmolik, M. Kulecki, J. Urwanowicz, Kórnik 1994, s. 58.

5 S. Alexandrowicz, Powstanie i rozwój miast województwa podlaskiego (XV - I połowa XVII w.), „Acta Balitco-Slavica", 1, 1964, s. 151.

6 O historii Bielska i jego zabytków patrz: Katalog zabytków sztuki. Województwo podlaskie (białostockie). Powiat bielski, oprac. Z. Michalczyk, D. Piramidowicz, K. Uchowicz, M. Zgliński, [w:] Katalog zabytków sztuki w Polsce. Seria Nowa, red. M. Zgliński, t. 12, z. 4, Warszawa 2019, s. 10-64.

7 Odnaleziono tam wiele artefaktów z okresu od X do XIII w. „Informator Archeologiczny. Badania. Rok 1976", 1977, s. 175; J. Maciejczuk, Sprawozdanie z badań i nadzorów archeologicznych w Bielsku Podlaskim na ulicy Zamkowej 26 VI - 15 IX 1997, mps, Wojewódzki Urząd Ochrony Zabytków w Białymstoku; K. Mazuruk, Stanowiska archeologiczne Bielska Podlaskiego na tle historiografii, „Białoruskie Zeszyty Historyczne”, 2004, 21, s. 135-136. W XVI w. w tym miejscu najprawdopodobniej nie istniała żadna ulica. Dopiero ulicę bez nazwy wymienia dokument z 1610 r., który ustanawiał wzdłuż niej Nową Osadę Podzamecką. Archiwum Główne Akt Dawnych w Warszawie [dalej: AGAD], Metryka Koronna [dalej: MK], dz. XVIII, sygn. 64, s. 569-570.

8 Kronika halicko-wołyńska (Kronika Romanowiczów), wyd., wstęp i przyp. D. Dąbrowski, A. Jusupowić, współpr. I. Juriewa, A. Majorow, T. Wiłkuł, Kraków-Warszawa 2017, Pomniki Dziejowe Polski, ser. 2, t. 16, s. 328-329.

9 W. Szymański, Komunikato wynikach sondażowych badań grodzisk w Bielsku Podlaskim i we Wnorach-Wypychach, „Rocznik Białostocki”, 13, 1976, s. 502. 
znajdowała się osada. Straciła ona swoje znaczenie wraz ze wzniesieniem zamku w innym miejscu i po ustanowieniu wójtostwa w 1430 r. ${ }^{10}$ Później osadnictwo rozwijało się na północy, wzdłuż Traktu Wileńskiego (w XVI w. ul. Wielka i Litewska, dziś ul. Adama Mickiewicza) i późniejszej ul. Stare Miasto (dziś część ul. Jagiellońskiej). W różnych okresach powstawały tam nowe osady, które stały się następnie dzielnicami Bielska ${ }^{11}$.

Po zajęciu Bielska przez Litwinów w połowie XIV w. funkcję grodu przejął zbudowany przez nich drewniany zamek ${ }^{12}$. Nieznana jest jego dokładna lokalizacja $^{13}$. W XVI w. zamek zmienił swoją funkcję - z obronnej na siedzibę władz i miejsce pobytu władców ${ }^{14}$. Przestał istnieć 22 lipca $1564 \mathrm{r}^{15}$. Bielsk poza zamkiem nie miał innych fortyfikacji.

10 K. Mazuruk, op. cit., s. 135-138.

11 W. Bukowski, D. Michaluk, Najdawniejsze przywileje królewskiego miasta Bielska w XV i XVI w., Ciechanowiec-Warszawa 2018, s. 16 (Lokacje miast podlaskich).

12 O tym, że zamek był drewniany, dowiadujemy się m.in. z relacji A. Gwagnina: „Zamek był drzewiany, ale spalony" (idem, Z kroniki Sarmacji europejskiej. Opisanie Polski, W. Ks. Litewskiego, Ziemie ruskiej, Ziemie pruskiej, Ziemie inflandzkiej, Ziemie żmudzkiej, wyd. K.J. Turowski, Kraków 1860, s. 25).

13 Początkowo uważano, że zamek wzniesiono w miejscu dawnego grodu, obecnie nazywanego błędnie Górą Zamkową. J. Jaroszewicz, Miasto Bielsk, wstęp B. Białokozowicz, tłum. J. Ostapkowicz, Bielsk Podlaski 2007, s. 103; Ф.В. Покровский, Археологическая карта Гробненской губернии, Вильна 1896. Twierdzenie to zostało obalone w trakcie badań archeologicznych W. Szymański, loc. cit. J. Zieleniewski postawił hipotezę, że zamek litewski znajdował się pomiędzy ulicami widocznymi na planie Bielska w AHP: Zalubecką, Zamkową i nienazwaną ulicą (w XVII-XVIII w. ul. Podzamecką, obecnie ul. G. Narutowicza). Zieleniewski na potwierdzenie swojej hipotezy przytoczył kilka istotnych argumentów. Rejestr pomiary włócznej wspominał, że ul. Wielka biegła z rynku miejskiego do zamku. Kończyła się przy skrzyżowaniu z ul. Zamkową, a przedłużeniem ul. Wielkiej była ul. Zalubecka. Wraz z nienazwaną ulicą (dziś ul. G. Narutowicza) tworzyły one wrzecionowaty plac, na którym miał stać zamek. Idem, Bielsk Podlaski - topografia historyczna w XII-XVIII w., Białystok 1980-1981, praca magisterska pod kier. prof. S. Alexandrowicza, mps, s. 10; idem, Średniowieczny zespół osadniczo-obronny w Bielsku Podlaskim. Siedziba namiestników bielskich w panoramie miasta z pierwszej połowy XVI w., [w:] Europa Orientalis. Polska i jej wschodni sąsiedzi od średniowiecza po współczesność. Studia i materiały ofiarowane Profesorowi Stanisławowi Alexandrowiczowi w 65. rocznicę urodzin, red. Z. Karpus, T. Kempa, D. Michaluk, Toruń 1996, s. 117-119, 124-125.

14 Pobyty władców w Bielsku potwierdzają ich opublikowane itineraria. Zob. A. Gąsiorowski, Itineraria dwu ostatnich Jagiellonów, „Studia Historyczne”, 16, 1973, s. 249-275; K. Pietkiewicz, Itinerarium króla Aleksandra Jagiellończyka 1492-1506, Warszawa 2016; S. Polechow, Itinerarium wielkiego księcia litewskiego Witolda: 4/5 sierpnia 1392-27 października 1430, „Rocznik Lituanistyczny”, 5, 2019, s. 9-120; M. Wrede, Itinerarium króla Stefana Batorego 1576-1586, Warszawa 2010; idem, Itinerarium króla Zygmunta III 1587-1632, Warszawa 2019.

15 „Piorun wierzchni zamek spalił, który ogień tak prędko moc wziął, że za dwie godziny nie tylko wierzchni, ale i dolny zamek ze wszystkim jako umiotł zgorzał: na który ogień król [Zygmunt August - M.S.] na koniu u stajen stojąc patrzał". Zbiór dziejopisów polskich w czterech tomach zawartych, t. 1: Kronika Marcina Bielskiego niegdyś w Krakowie drukowana, teraz znowu doprowadzeniem aż do Augusta III przedrukowana, wyd. F. Bohomolec, Warszawa 1764, s. 561. Informacja ta nie jest dokładna, gdyż 10 lipca król opuścił Bielsk i udał się do Parczewa. W. Bukowski, D. Michaluk, 
Bielsk uzyskiwał prawa miejskie $\mathrm{w}$ dwóch etapach ${ }^{16}$. Pierwszym było nadanie 2 stycznia 1430 r. przez wielkiego księcia litewskiego Witolda dziedzicznego wójtostwa. Przywilej ten pozwalał osiedlać się w Bielsku tylko Polakom i Niemcom wyznania katolickiego, jednak miano nie czynić krzywdy mieszkającym już tam Rusinom ${ }^{17}$. Dokument ten wprowadzał w Bielsku dwa porządki prawne. Na północy powstało wtedy Miasto Lackie, gdzie obowiązywało prawo niemieckie. W części ruskiej, zwanej Starym Miastem, mieszkali Rusini, rządzący się wciąż prawem ruskim. Obejmowała ona w XVI w. ul. Stare Miasto ${ }^{18}$, okolicę grodu, zamku, osadę Podzamecką i osadę Kłopoty ${ }^{19}$ - położoną na południe od późniejszego kościoła farnego, wzdłuż XVI-wiecznej ul. Kłopotowskiej, aż do ul. Zarynek ${ }^{20}$.

Prawo magdeburskie Bielsk uzyskał od wielkiego księcia litewskiego Aleksandra Jagiellończyka w listopadzie 1495 r. Objęło ono wszystkich mieszkańców Bielska wraz z ludnością okręgu miejskiego. W różnym czasie w tym okręgu powstały wsie miejskie: Augustowo, Stryki (w XVI w. Młodzianowo lub Stryki), Szastały (w XVI w. Koszczyno lub Szastały), Widowo (w XVI w. Stanisławowo, w XVII w. Widowo lub Stanisławowo), Parcewo (w XVI w. Piotrowo) i Spiczki. Do prawa miejskiego dołączono również osadę garbarską Dubicze, znajdującą się po drugiej stronie rzeki Białej ${ }^{21}$. Jurysdykcji miejskiej mieli się poddać także

op. cit., s. 18. Bezpośrednio przed pożarem zamku w Bielsku obradował sejm Wielkiego Księstwa Litewskiego. Por.: A. Rachuba, Wielkie Księstwo Litewskie w systemie parlamentarnym Rzeczypospolitej 1569-1763, Warszawa 2002, s. 45-46.

16 Bielsk jeszcze przed uzyskaniem prawa magdeburskiego pod względem gospodarczym miał już charakter miejski. Mimo to, tak jak wiele podobnych osiedli w Wielkim Księstwie Litewskim, do momentu uzyskania praw miejskich podlegał prawu książęcemu.

17 W. Bukowski, D. Michaluk, op. cit., s. 67-69.

18 Badania archeologiczne wskazują, że ta część Bielska była zamieszkana przynajmniej od XV w. W południowej części Starego Miasta znaleziono również starsze zabytki archeologiczne. Z. Misiuk, Badania archeologiczne w Bielsku Podlaskim na ul. Poniatowskiego 14 przeprowadzone we wrześniu 2003 r., „Białoruskie Zeszyty Historyczne”, 23, 2005, s. 169.

19 Według badań archeologicznych teren osady Kłopoty był zamieszkały przynajmniej od drugiej połowy XIV w. Zob.: L. Pawlata, Badania archeologiczne na starym mieście w Bielsku Podlaskim na tle wyników dotychczasowych badań, „Biuletyn Konserwatorski Województwa Podlaskiego”, 21, 2015, s. 271.

20 W. Bukowski, D. Michaluk, op. cit., s. 18. Patrz: AHP, plan: Bielsk Podlaski w 1563 r.

21 W. Bukowski, D. Michaluk, op. cit., s. 23. Badacze dziejów Bielska wymieniają również osadę garbarską Zastawie, która miała się znajdować w południowej części dzisiejszej ul. Dubicze. Prowadzone kwerendy nie wykazały osady o takiej nazwie w XVI w., dlatego też nie znalazła się ona na planie Bielska w AHP. O istnieniu osady o takiej nazwie jako pierwszy pisał J. Zieleniewski, jednak nie zaznaczył jej na opracowanym przez siebie planie miasta w $1563 \mathrm{r}$. Umieścił za to na tym planie ul. Zastawiecką. Sama osada Zastawie znalazła się dopiero na stworzonym przez niego planie Bielska w XVIII w. J. Zieleniewski, Powstanie i rozwój układu przestrzennego Bielska Podlaskiego w XIV-XVIII wieku, „Studia Podlaskie”, 1, 1990, s. 64, plan [1] Bielsk Podlaski. Układ przestrzenny w 1563 roku, 
„ludzie Kolyenki czyli Kolyenkowicze”22. Dokument nie objął jedynie osady Podzameckiej, która przekształcona została w jurydykę starościńską z własnym wójtem ${ }^{23}$. W latach 1499 i 1501 Aleksander Jagiellończyk potwierdził i rozszerzył prawa miejskie przysługujące Bielskowi ${ }^{24}$.

Największy wpływ na układ przestrzenny Bielska wywarła pomiara włóczna. Jej podstawę stanowiły Ustawy na wołoki z $1557 \mathrm{r}^{25}$ Znamy wzmianki o trzech pomiarach w Bielsku i okręgu miejskim. Pierwsza miała rozpocząć się już w 1540 r., gdy włość bielska była w ręku królowej Bony ${ }^{26}$. Nie wiadomo, czy doszła do skutku i jakie były jej rezultaty. Za panowania Zygmunta Augusta w mieście i przedmieściach pomiara odbyła się dwukrotnie. Pierwsza będzie nas najbardziej interesować. W 1560 r. realizował ją Stanisław Dziewiałtowski Skoczek. Nie stosował się on w pełni do wymogów Ustawy na wołoki i wskazań hospodarskich, nie przejmował się również prawami poddanych. Został przez to odsunięty od obowiązków ${ }^{27}$.

plan [2] Bielsk Podlaski. Układ przestrzenny w XVIII wieku, po s. 328. Około 1563 r. ulica o nazwie Zastawiecka nie istniała. Była to nienazwana ulica położona między ul. Grobelną a Łoknicką. J. Zieleniewski informację o tej ulicy zaczerpnął zapewne z inwentarza z 1779 r. Описаніе Рукопснаго Отдьленія Виленской Публичной Библіотеки, t. 4, Wilno 1903, s. 78-81. Ulica ta została wymieniona w 1663 r. Muzeum Podlaskie w Białymstoku [dalej: MPwB], sygn. H/D/506 (rękopis niejednorodnie paginowany). Za zwrócenie mi uwagi na tę sygnaturę dziękuję dr. T. Jaszczołtowi. Inwentarz z 1772 r. nie wspomina o tej ulicy i osadzie. Vilniaus universiteto biblioteka [dalej: BUWil], sygn. F4-A1661. Na planie Bielska z 1834 r. również nie znalazła się ul. Zastawiecka - tylko ul. Dubicka. Нацььянальны гістарычны архіў Беларусі Гродна [dalej: NGAB Grodno], f. 126-1-105. Ulicę tę wymienia J. Jaroszewicz w swym opisie miasta z 1845 r. J. Jaroszewicz, op. cit., s. 134.

22 Była to najprawdopodobniej ruska ludność pośrednia między szlachtą a chłopstwem. Nie wiemy, gdzie mieszkali początkowo. Najprawdopodobniej w trakcie pomiary włócznej zostali przesiedleni na tereny zwane na Kolence na północy miasta po obu stronach Traktu Wileńskiego. W. Bukowski, D. Michaluk, op. cit., s. 23-24, 73-76. Zob. J. Zieleniewski, Powstanie i rozwój układu..., s. 64-65, plan Bielsk Podlaski. Układ przestrzenny w 1563 roku.

23 J. Zieleniewski, Powstanie i rozwój układu..., s. 69; J. Jaroszewicz, op. cit., s. 147.

24 W. Bukowski, D. Michaluk, op. cit., s. 79-88.

25 Więcej na temat pomiary włócznej: J. Jaroszewicz, Obraz Litwy pod względem jej cywilizacji od czasów najdawniejszych do końca wieku XVIII, cz. 2: Litwa w pierwszych trzech wiekach po przyjęciu wiary chrześcijańskiej, Wilno 1844, s. 229-275; J. Ochmański, Dawna Litwa. Studia historyczne, Olsztyn 1986, s. 158-197.

26 J. Zieleniewski, Powstanie i rozwój układu..., s. 57.

27 Zob. Archiwum Państwowe w Białymstoku [dalej: APwB], Kamera Wojny i Domen [dalej: KWiD], sygn. 2816, k. 3v; J. Maroszek, Katolicy - unici w Bielsku Podlaskim w latach 1596-1839, [w:] Bielsk Podlaski. Studia i materiały do dziejów miasta, red. Z. Romaniuk, Bielsk Podlaski 1999, s. 72-73. W przywileju z $1565 \mathrm{r}$. król prezentował swą motywację do przeprowadzenia ponownej pomiary: „Zobaczywszy, że ich [mieszczan bielskich - M.S.] miejskie ziemie między naszymi folwarkami i poddanymi włości [naszych] nie mogły być zgodnie ze swoim prawem jako sioła osadzone i w spokoju, wtedy poleciliśmy na nowo tę pomiarę niedobrą zmienić”. W. Bukowski, D. Michaluk, op. cit., s. 97. Tak zaś opisywał postać Dziewiałtowskiego Łukasz Górnicki: „Miernicy jeździli po Podlaszu, w bielskim powiecie, nad którymi był od króla superintendentem niejaki Stanisław Skoczek [...]. A iż ten Skoczek nieludzce się obchodził z ludźmi, tak iż czasem przez pojśrzodek 
Dalsze prace prowadził Andrzej Dybowski i Adam Pilchowski ${ }^{28}$. Pomiara zakończyła się w $1563 \mathrm{r}^{29}$

Układ urbanistyczny Bielska w trakcie pomiary włócznej został ułożony wzdłuż głównych ulic idących w linii północ-południe. Najważniejszą oś miasta stanowiły ulice Wielka i Litewska. Wzdłuż lub w okolicy tych ulic znajdowały się najważniejsze punkty na mapie miejskiej - centralnie położony rynek, zamek umiejscowiony gdzieś na południowym krańcu miasta i świątynie. Układ przestrzenny miasta $\mathrm{z}$ okresu pomiary włócznej jest widoczny do dziś.

Tylko ostatnia z pomiar włócznych zachowała się do dziś w postaci rejestru. Takie rejestry były spisywane również przy innych podlaskich królewszczy$z$ znach $^{30}$. Dla pomiary sporządzonej przez Andrzeja Dybowskiego badacze do niedawna posługiwali się tylko fragmentarycznym odpisem, który uwzględniał głównie parcele należące do instytucji religijnych ${ }^{31}$. W ostatnim czasie został odkryty pełen rejestr tej pomiary włócznej ${ }^{32}$. Pomiara wykonana w Bielsku przez Stanisława Dziewiałtowskiego Skoczka przetrwała jedynie jako notatka ${ }^{33}$. Nie jest to wypis źródłowy tylko spis ulic, które wynotowała osoba spisująca notatkę. Autor i cel jej sporządzenia nie jest znany. Według karty katalogowej tej sygnatury archiwiści z Biblioteki Uniwersytetu Wileńskiego (Vilniaus universiteto biblioteka) podejrzewają, że została ona sporządzona w XIX w., co jest dość prawdopodobne i na co wskazuje też dukt pisma. Wcześniej dokument ten znajdował się w zbiorach Muzeum Starożytności w Wilnie ${ }^{34}$. Mimo, iż jest

izby sznur miernikom ciągnąć kazał, dziury poprzewierciawszy, odjął też był niesłusznie niejakiemu Wojcikowi niemało gruntu. Ten Wojcik kilkakroć królowi się skarżył o tę krzywdę”. Ł. Górnicki, Dzieje w Koronie Polskiej, oprac. H. Barycz, Wrocław 2003, s. 143-144.

AGAD, Zbiór Ignacego Kapicy Milewskiego „Kapicjana”, sygn. 10, s. 33-37; APwB, KWiD, sygn. 2816, k. 3-4; W. Bukowski, D. Michaluk, op. cit., s. 95-97; J. Maroszek, op. cit., s. 72-73. APwB, KWiD, sygn. 2816, k. 19-23v; MPwB, sygn. H/D/506.

30 Rejestry zachowały się m.in. dla Brańska, Suraża, Narwi i Kleszczel. Акты издаваемые Виленскою Археографическою Коммиссіею, t. 14: Инвентари импний XVI-го столютюя, Вильна 1888, s. 24-76; Rejestr pomiary włócznej Kleszczel z roku 1560, oprac. J. Zieleniewski, „Studia Podlaskie”, 3, 1991, s. 201-250; J. Kazimierski, Rejestr pomiarowy miasta Suraża z roku 1562, „Teki Archiwalne”, 1954, s. 138-191.

31 APwB, KWiD, sygn. 2816, k. 19-20v.

$32 \mathrm{MPwB}$, sygn. H/D/506. W tym poszycie poza pomiarą włóczną znajduje się jeszcze kilka innych dokumentów.

33 BUWil, sygn. F5-A41-7932. Za udostępnienie mi fotografii tego źródła dziękuję dr. A. Buczyle. W Bibliotece Uniwersytetu Wileńskiego wśród rękopisów zachowała się też kopia innego fragmentu najprawdopodobniej tej pomiary. Dotyczy ona młynów w starostwie bielskim. BUWil, sygn. F4-A1660; Fragment lustracji starostwa bielskiego z 1560 r., „Bielski Almanach Historyczny”, 2016, s. 157-158. Kopia tej pomiary dla wsi Kotłów i Trześcianki (w XVI w. Trościanica): AGAD, Archiwum Roskie, sygn. 1115, s. 1-7; zaś dla wsi Stryki: MPwB, sygn. H/D/506.

34 BUWil, sygn. F5-A41-7932. 
to tylko notatka, jest ona niezwykle cenna, gdy weźmie się pod uwagę źródła, które mogą pomóc w rekonstrukcji układu urbanistycznego Bielska w XVI w. Poza pomiarą Andrzeja Dybowskiego posiadamy niewnoszące zbyt wiele informacji o układzie przestrzennym lustracje z 1576, 1602 i 1664 r., a także enigmatyczne inwentarze z XVII w. ${ }^{35}$ Niewiele danych przynoszą inne źródła skarbowe z XVI i XVII w. ${ }^{36}$ Pierwsze szczegółowe inwentarze po $1563 \mathrm{r}$. pochodzą dopiero z $1772^{37}$ i $1779 \mathrm{r}^{38}$ Zachowane księgi miejskie obejmują dopiero drugą połowę XVII i XVIII w. ${ }^{39}$ Pierwszy znany plan ukazujący schematycznie układ przestrzenny miasta pochodzi dopiero z $1781 \mathrm{r}^{40}$ Późniejsze szczegółowe plany pochodzą z 1830 i 1834 r. $^{41}$

Poniższa edycja źródłowa jest wiernym oddaniem źródła, jedynie z małymi ingerencjami $\mathrm{w}$ jego zapisy ${ }^{42}$. Została ona tak wykonana, by nie zniekształcić notatki, która głównie zawiera nazwy własne będące nazwami ulic w Bielsku. Stąd też nie uwspółcześniano pisowni. Notatka została spisana na jednej karcie o wymiarach $33 \times 20,5 \mathrm{~cm}$. Poza tą kartą nie znajdują się inne dokumenty w sygnaturze F5-A41-7932. Wchodzi ona w skład fondu 5 (Mišrus), do którego należą mieszane materiały o różnej proweniencji i tematyce. Po trzech pierwszych akapitach treści zostały naniesione po wcięciu akapitowym sięgającym 2/5 całej karty. Nie zostało to wprowadzone w niniejszej edycji. Po 1/3 notatki można zauważyć, że pismo jest bardziej wyblakłe niż we wcześniejszym fragmencie. Zachowane zostały też wszystkie podkreślenia zastosowane w notatce

35 AGAD, MK, dz. XVIII, sygn. 64, s. 564-580; MPwB, sygn. H/D/506; Lustracja województwa podlaskiego 1602 roku, wyd. M. Sierba, Warszawa 2017, s. 63-66; Lustracje województwa podlaskiego 1570 i 1576, wyd. J. Topolski, J. Wiśniewski, Wrocław-Warszawa 1959, s. 29-31.

36 Patrz m.in.: AGAD, Archiwum Skarbu Koronnego, dz. I, sygn. 47, k. 145-147, 300, 480-481, 648651, 787, 791v; sygn. 70, k. 370, 437-437v; dz. LIV, sygn. 29, k. 2v, 5-5v, 43, 48-49; APwB, Księgi grodzkie i ziemskie podlaskie, Księga grodzka brańska 1640-1641, k. 26, 42; Biblioteka Książąt Czartoryskich w Krakowie, rkps. 1099, k. 840v.

37 BUWil, sygn. F4-A1661. Inwentarz ten jest $\mathrm{w}$ trakcie prac redakcyjnych $\mathrm{w}$ celu jego wydania drukiem.

38 Описаніе Рукопснаго..., s. 57-112.

39 AGAD, Bielskie miejskie, nr 1-3; NGAB Grodno, f. 877-2-1 i 2.

40 Plan zachował się do dzisiejszych czasów w odrysie z okresu międzywojennego. Autorowi nie jest znany oryginał tego odrysu. Przy analizach wykorzystano jedynie kserokopię znajdującą się w bielskim oddziale Muzeum Podlaskiego, która została umieszczona na czwartej stronie okładki pracy: Bielsk Podlaski. Studia i materiały do dziejów miasta, red. Z. Romaniuk, Bielsk Podlaski 1999.

41 NGAB Grodno, f. 126-1-105; Rosyjskie Państwowe Archiwum Historyczne w Petersburgu [dalej: RPAH Petersburg], f. 1293-166-10. Mapy te zostały szerzej omówione w: W. Konończuk, Nieznany plan Bielska z 1834 r. Z dziejów kształtowania się układu przestrzennego miasta, „Biuletyn Konserwatorski Województwa Podlaskiego", 26, 2020, s. 87-113.

42 Przy edycji wykorzystano wskazania instrukcji wydawniczej pod redakcją K. Lepszego: Instrukcja wydawnicza dla źródeł historycznych od XVI w. do połowy XIX w., red. K. Lepszy, Warszawa 1953. 
przez jej autora. Jednak postanowiono zamienić znak „_" na „-", gdyż w takiej funkcji stosował go autor notatki. Znaki „/" zamieniono na nawiasy. Zmieniono używane przez autora notatki wielkie i małe litery, przystosowując je do dzisiejszej pisowni. Do skrótu „ul” stosowanego w źródle dodano na końcu kropkę. Skrót „S” oddano w formie współczesnej „św.”. Każda z występujących w źródle ulic została opisana w przypisie z podaniem jej współczesnej nazwy, jak również $\mathrm{z}$ ewentualnym odniesieniem do pomiary włócznej Andrzeja Dybowskiego, planu sporządzonego na potrzeby Atlasu historycznego Polski i innych prób rekonstrukcji układu przestrzennego Bielska. Należy podkreślić, że współczesne ulice mogą posiadać nieco inny przebieg niż wymienione w źródle. 


\title{
ANEKS
}

\section{Notatka z rejestru pomiary włócznej Bielska sporządzonej przez Stanisława Dziewiałtowskiego Skoczka}

\author{
Bielsk \\ Notaty z lustracyi Dziewałtowskiego Skoczka ${ }^{43}$ \\ (braknie $2^{\text {ch }}$ kart początkowych) \\ $4^{\text {ta }}$ strona rynku idąc do cerkwi ruskiej św. Michała ${ }^{44}-$ dalej przerwana, \\ Dokończenie prawej połaci tejże ulicy Wielkiej Rynkowej ${ }^{45}$ do ulicy Zam- \\ kowej $^{46}$, podle popa Hleba ${ }^{47}$.
} opisanie siedzib.

Ulica Zaluboczka ${ }^{48}$ na goscińcu Krakowskim ${ }^{49}$ z Wielkiej ulicy Rinkowej połać prawa - (przedarte opisanie siedzib)

43 Stanisław Dziewiałtowski Skoczek był sługą króla Zygmunta Augusta. Marek Ferenc określa go jako dworzanina tytularnego, czyli osobę, która używała tytułu dworzanina, jednak nie występuje w żadnych spisach dworskich. Wspomina o nim z błędem w nazwisku, gdyż określa go jako Stanisława Dziewułtowskiego. M. Ferenc, Dwór Zygmunta Augusta. Organizacja i ludzie, wyd. II, Oświęcim 2014, s. 59. W dokumencie Metryki Koronnej faktycznie został on nazwany dworzaninem królewskim. AGAD, MK, sygn. 108, k. 279. Dziewiałtowski był nadzorcą mierników, którzy dokonywali pomiary włócznej w podlaskich królewszczyznach. Ł. Górnicki, op. cit., s. 143. Przeprowadził pomiary m.in. w starostwie bielskim, narewskim, kleszczelewskim, suraskim i brańskim. BUWil, sygn. F5-A41-7932; Акты издаваемье..., s. 24-76; Rejestr pomiary włócznej Kleszczel z roku $1560 \ldots$.., s. 201-250. Wobec nieprzestrzegania zasad Ustawy na wołoki, niestosowania się do poleceń królewskich i skarg poddanych został odsunięty od obowiązków, a pomiarę włóczną na Podlasiu dokończył Andrzej Dybowski i Adam Pilchowski.

44 Była najważniejszą świątynią prawosławną w mieście. Posiadała też wezwanie Objawienia Pańskiego. Pierwsza informacja o niej pochodzi dopiero z 1560 r., gdy została uposażona w 2 włóki w Strykach. Lietuvos Mokslų Akademijos Vrublevskių Biblioteka, f. 41-394, s. 851. Osadzono ją w południowej części ul. Wielkiej (dziś ul. A. Mickiewicza) przy wschodniej pierzei. Najprawdopodobniej jednak powstała przed 1560 r., w trakcie organizacji tej części miasta. W drugiej połowie XVI w. pełniła funkcję cerkwi soborowej i głównej świątyni prawosławnej w mieście. APwB, KWiD, sygn. 2816, k. 19-23v; MPwB, sygn. H/D/506; D. Fionik, G. Sosna, Dzieje cerkwi w Bielsku Podlaskim, Białystok 1995, s. 21, 121-122; J. Jaroszewicz, Miasto Bielsk..., s. 115; A. Mironowicz, Podlaskie ośrodki i organizacje prawostawne w XVI i XVII wieku, Białystok 1991, s. 102; W. Bukowski, D. Michaluk, op. cit., s. 20.

45 Dziś ul. A. Mickiewicza w odcinku od ul. J. Poniatowskiego do rynku. Została oznaczona na planie Bielska w AHP.

46 Dziś ul. J. Poniatowskiego do skrzyżowania z ul. Zamkową. Została oznaczona na planie Bielska w AHP.

47 Pełnił posługę w cerkwi św. Michała i Objawienia Pańskiego. Jego posesja znajdowała się na zachodniej pierzei ul. Wielkiej, mniej więcej w połowie jej biegu.

48 Dziś południowy fragment ul. A. Mickiewicza od ul. J. Poniatowskiego. Dalszy jej bieg to północny fragment ul. Wojska Polskiego. Została oznaczona na planie Bielska w AHP jako ul. Zalubecka.

49 Trakt prowadzący w stronę miasta Boćki. Stamtąd można było kierować się do Warszawy, Krakowa czy Lublina. Zaznaczona na planie Bielska w AHP jako „Droga do Bociek”. Patrz: M. Sierba, Drogi, w: AHP. 
Lewa połać tej ulicy

Rzeka Lubka ${ }^{50}$

Ulica $^{51}$, która idzie z rynku gościńcem wileńskim ${ }^{52}$

Droga do Młynów ${ }^{53}$

Ulica Litewska ${ }^{54}$

Nowe place na tej ulicy - ulica Wielka czyli Litewska - ulica Kondratowska $^{55}$ - ulica Knyszyńska ${ }^{56}$ - ulica wielka Zachawecka ${ }^{57}$, ulica Hryczowska $^{58}$, ulica idąca od kościoła fary ${ }^{59}$, ul. Kłopotowica ${ }^{60}$ od kościoła fary,

50 Dopływ rzeki Białej. Źródła Lubki znajdują się na południowy zachód od XVI-wiecznego miasta.

51 Dziś fragment ul. A. Mickiewicza między rynkiem a zespołem pokarmelickim. Zaznaczona na planie Bielska w AHP jako ul. Litewska zgodnie z zapisem z rejestru pomiary włócznej sporządzonej przez Andrzeja Dybowskiego: „Ulica Litewska, która idzie z rynku Gościńcem Wileńskim ku miastu Narwi". MPwB, sygn. H/D/506.

52 Trakt w XVI w. prowadzący przez Bielsk do Grodna i Wilna przez miasto Narew. Patrz: M. Sierba, Drogi, w: AHP.

53 Dziś ul. Widowska. Zaznaczona na planie Bielska w AHP.

54 Dziś ul. A. Mickiewicza od zespołu pokarmelickiego na północny wschód. Zaznaczona na planie Bielska w AHP jako ul. Litewska jednak o dłuższym biegu, bo rozpoczynała się od rynku. Patrz: przyp. 45.

55 Dziś ul. Kryniczna i J. Dąbrowskiego. Zaznaczona na planie Bielska w AHP.

56 Dziś ul. Żwirki i Wigury. Zaznaczona na planie Bielska w AHP. Jej dalszy ciąg stanowił trakt prowadzący przez Suraż do Knyszyna lub Tykocina. W rejestrze pomiary włócznej sporządzonym przez Andrzeja Dybowskiego zapisano: „Ulica Knyszyńska do paszen mie[j]skich na zachód słońca”. $\mathrm{MPwB}$, sygn. H/D/506.

57 Nieznane jest położenie i przebieg tej ulicy. Być może biegła wzdłuż zachodniego krańca miasta i łączyła ul. Knyszyńską z drogą do Brańska. J. Zieleniewski zaznaczył na stworzonej przez siebie rekonstrukcji układu przestrzennego Bielska z 1563 r. i XVIII w. Gościniec Brański (dziś al. J. Piłsudskiego). J. Zieleniewski, Powstanie i rozwój układu..., s. 47-70, plan Bielsk Podlaski. Układ przestrzenny w 1563 roku, plan Bielsk Podlaski. Układ przestrzenny w XVIII wieku. Możliwe, że nazwa ulica wielka Zachawecka odnosi się do innej ulicy. Jednak kolejność wymienionych nazw ulic sugeruje, że mogło chodzić o dzisiejszą al. J. Piłsudskiego. W pierwszej połowie XIX w. nazywano ją ul. Zagumienną. NGAB Grodno, f. 126-1-105; RPAH Petersburg, f. 1293-166-10. Ulica ta nie została zaznaczona na planie Bielska w AHP.

58 Dziś ul Kazimierzowska od ul. A. Mickiewicza do ul. Ogrodowej, która następnie w nią skręcała i biegła aż do ul. Widowskiej. Zaznaczona na planie Bielska w AHP jako ul. Hrycowska.

59 Kościół farny znajdował się w tym samym miejscu co obecnie - na zachód od rynku. Parafię ufundowano najprawdopodobniej ok. 1430 r., choć pierwsze informacje źródłowe pochodzą dopiero z 1446 r. Parafia była i jest pod wezwaniem Narodzenia NMP i św. Mikołaja. Lietuvos Metrika. Knyga $n r 3$ (1440-1498), wyd. L. Anužytè, A. Baliulis, Vilnius 1998, s. 28. Więcej o historii parafii: E. Beszta-Borowski, Dzieje parafii katolickiej Narodzenia Najświętszej Maryi Panny i św. Mikołaja w Bielsku Podlaskim, Drohiczyn-Warszawa 2012. Możliwe, że w notatce chodzi o dzisiejszą ul. Poświętną, gdyż jako następna wymieniona jest ul. Kłopotowica - czyli dzisiejsza ul. T. Kościuszki. Wzdłuż ul. Poświętnej w XVI w. rozciągała się jurydyka kościelna. J. Zieleniewski, Bielsk Podlaski - topografia historyczna..., s. 13. Ulica zaznaczona na planie Bielska w AHP bez nazwy.

60 Dziś ul. T. Kościuszki. Zaznaczona na planie Bielska w AHP jako ul. Kłopotowska. 
ul. przussda ${ }^{61}$ zamkowy $^{62}$ - za cerkwią św. Mikuły ${ }^{63}$ - ul. Zamkowa, place miejskie podle cerkwi św. Mikołaja naprzeciwko stajni królewskich ${ }^{64}$ - uliczka Dziekil $^{65}$ - ul. Starego Miasta ${ }^{66}$, ul. Dubicka ${ }^{67}$ i Brzeska $^{68}$ nowe, poczyna się od ściany folwar ${ }^{69}$ zamkowego $^{70}$ idąc ku młynowi szpitalnemu - (rzeka Biała $)^{71}$ - kościół ruski założenia Zmartwychwstania Pańskiego ${ }^{72}$ - uliczka Krzyżowa $^{73}$.

Źródło: Vilniaus universiteto biblioteka, F5-A41-7932

61 Wyraz napisany nieczytelnie. Najprawdopodobniej chodzi o słowo przysuda. Tego słowa użyto również w rejestrze pomiary włócznej z $1563 \mathrm{r}$. w odniesieniu do terenów należących do jurydyki zamkowej. MPwB, sygn. H/D/506.

62 Jeśli pełne określenie stanowiłoby $u l$. przysuda zamkowy to najprawdopodobniej chodzi o dzisiejszą ul. G. Narutowicza, którą w XVII i XVIII w. określano jako ul. Podzamecką. Znajdowała się tam jurydyka zamkowa. Ulica ta została zaznaczona na planie Bielska w AHP bez nazwy.

63 W znaczeniu: św. Mikołaja. Chodzi o monaster i cerkiew, które znajdowały się przy skrzyżowaniu dzisiejszej ul J. Poniatowskiego z ul. Zamkową. Obecnie na terenie pomonasterskim znajduje się szkoła i mała kaplica. Zaznaczona na planie Bielska w AHP.

64 Stajnie królewskie znajdowały się najprawdopodobniej na północno-wschodnim rogu skrzyżowania dzisiejszej ul. J. Poniatowskiego i Zamkowej. Zaznaczone na planie Bielska w AHP.

65 Dziś ul. M. Kopernika. Została zaznaczona na planie Bielska w AHP jako ul. Dziechil.

66 Dziś ul. Jagiellońska od ul. M. Kopernika do ul. Kazimierzowskiej. Zaznaczona na planie Bielska w AHP jako ul. Stare Miasto.

67 Dziś północna część ul. Dubicze - między ul. Warzywną a Widowską. Znajdowała się na wschodnim brzegu rzeki Białej. Zaznaczona na planie Bielska w AHP.

68 Dziś ul. S. Batorego. Zaznaczona na planie Bielska w AHP.

69 Skrótowy zapis od słowa: folwarku.

70 Folwark znajdował się w Hołowiesku, który stanowi dziś południowo wschodnią część Bielska.

71 Rzeka będąca lewym dopływem Orlanki, która stanowi lewy dopływ Narwi.

72 Cerkiew pw. Zmartwychwstania Pańskiego znajdowała się tam, gdzie obecnie - przy skrzyżowaniu ul. S. Batorego i R. Traugutta, czyli w XVI w. ul. Brzeskiej i Orlańskiej idącej do folwarku w Hołowiesku. Zaznaczona na planie Bielska w AHP. Cerkiew ta najprawdopodobniej została przeniesiona do Bielska ze wsi Lewki. Usytuowano ją na trójkątnym placu u zbiegu XVI-wiecznej ul. Dubickiej i Łoknickiej (dziś ul. Warzywna) po prawej stronie rzeki Białej. W trakcie pomiary włócznej cerkiew przeniesiono w jej obecne miejsce. W. Bukowski, D. Michaluk, op. cit., s. 25; J. Jaroszewicz, Miasto Bielsk..., s. 106.

73 Nieznana bliżej ulica. Nie została zaznaczona na planie Bielska w AHP. 


\section{Bibliografia}

\section{Źródła rękopiśmienne}

Archiwum Główne Akt Dawnych w Warszawie

- Archiwum Roskie, sygn. 1115

- Archiwum Skarbu Koronnego, dz. I, sygn. 47, 70; dz. LIV, sygn. 29

- Bielskie miejskie, nr 1-3

- Metryka Koronna, Księgi Wpisów, sygn. 108; dz. XVIII, sygn. 64

- Zbiór Ignacego Kapicy Milewskiego „Kapicjana”, sygn. 10

Archiwum Państwowe w Białymstoku

- Kamera Wojny i Domen, sygn. 2816

- Księgi grodzkie i ziemskie podlaskie, Księga grodzka brańska 1640-1641

Biblioteka Książąt Czartoryskich w Krakowie

- rkps. 1099

Lietuvos Mokslų Akademijos Vrublevskių Biblioteka

- f. 41-394

Muzeum Podlaskie w Białymstoku

- sygn. H/D/506

Нацыянальны гістарычны архіў Беларусі Гродна

- f. 126-1-105; f. 877-2-1-2.

Rosyjskie Państwowe Archiwum Historyczne w Petersburgu

- f. 1293-166-10

Vilniaus universiteto biblioteka

- sygn. F4-A1660, F4-A1661; F5-A41-7932

\section{Źródła drukowane}

Bukowski W., Michaluk D., Najdawniejsze przywileje królewskiego miasta Bielska w XV i XVI w., Ciechanowiec-Warszawa 2018.

Fragment lustracji starostwa bielskiego z 1560 r., „Bielski Almanach Historyczny”, 2016.

Górnicki Ł., Dzieje w Koronie Polskiej, oprac. H. Barycz, Wrocław 2003.

Gwagnin, Z kroniki Sarmacji europejskiej. Opisanie Polski, W. Ks. Litewskiego, Ziemie ruskiej, Ziemie pruskiej, Ziemie inflandzkiej, Ziemie żmudzkiej, wyd. K.J. Turowski, Kraków 1860. Kazimierski J., Rejestr pomiarowy miasta Suraża z roku 1562, „Teki Archiwalne”, 1954. Kronika halicko-wołyńska (Kronika Romanowiczów), wyd., wstęp i przyp. D. Dąbrowski, A. Jusupowić, współpr. I. Juriewa, A. Majorow, T. Wiłkuł, Kraków-Warszawa 2017, Pomniki Dziejowe Polski, ser. 2, t. 16. 
Lietuvos Metrika. Knyga nr 3 (1440-1498), wyd. L. Anužytė, A. Baliulis, Vilnius 1998. Lustracja województwa podlaskiego 1602 roku, wyd. M. Sierba, Warszawa 2017.

Lustracje województwa podlaskiego 1570 i 1576, wyd. J. Topolski, J. Wiśniewski, WrocławWarszawa 1959.

Rejestr pomiary włócznej Kleszczel z roku 1560, oprac. J. Zieleniewski, „Studia Podlaskie”, 3, 1991.

Zbiór dziejopisów polskich w czterech tomach zawartych, t. 1: Kronika Marcina Bielskiego niegdyś w Krakowie drukowana, teraz znowu doprowadzeniem aż do Augusta III przedrukowana, wyd. F. Bohomolec, Warszawa 1764.

Акты издаваемые Виленскою Археографическою Коммиссюю, t. 14: Инвентари импній XVI-го столютия, Вильна 1888.

Описаніе Рукопснаго Отдьленія Виленской Публичной Библіотеки, t. 4, Wilno 1903.

\section{Literatura przedmiotu}

Atlas historyczny Polski. Województwo podlaskie w drugiejpołowie XVIw., red. M. Gochna, B. Szady, Warszawa 2021 [w druku].

Beszta-Borowski E., Dzieje parafii katolickiej Narodzenia Najświętszej Maryi Panny i św. Mikołaja w Bielsku Podlaskim, Drohiczyn-Warszawa 2012.

Ferenc M., Dwór Zygmunta Augusta. Organizacja i ludzie, wyd. II, Oświęcim 2014.

Fionik D., Sosna G., Dzieje cerkwi w Bielsku Podlaskim, Białystok 1995.

Gąsiorowski A., Itineraria dwu ostatnich Jagiellonów, „Studia Historyczne”, 16, 1973.

„Informator Archeologiczny. Badania. Rok 1976”, 10, 1977.

Instrukcja wydawnicza dla źródeł historycznych od XVI w. do połowy XIX w., red. K. Lepszy, Warszawa 1953.

Jaroszewicz J., Miasto Bielsk, wstęp B. Białokozowicz, tłum. J. Ostapkowicz, Bielsk Podlaski 2007.

Jaroszewicz J., Obraz Litwy pod względem jej cywilizacji od czasów najdawniejszych do końca wieku XVIII, cz. 2: Litwa w pierwszych trzech wiekach po przyjęciu wiary chrześcijańskiej, Wilno 1844.

Katalog zabytków sztuki. Województwo podlaskie (białostockie). Powiat bielski, oprac. Z. Michalczyk, D. Piramidowicz, K. Uchowicz, M. Zgliński, [w:] Katalog zabytków sztuki w Polsce. Seria Nowa, red. M. Zgliński, t. 12, z. 4, Warszawa 2019.

Konończuk W., Nieznany plan Bielska z 1834 r. Z dziejów kształtowania się układu przestrzennego miasta, „Biuletyn Konserwatorski Województwa Podlaskiego” 26, 2020.

Maciejczuk J., Sprawozdanie z badań i nadzorów archeologicznych w Bielsku Podlaskim na ulicy Zamkowej 26 VI - 15 IX 1997, mps, Wojewódzki Urząd Ochrony Zabytków w Białymstoku. 
Maroszek J., Katolicy - unici w Bielsku Podlaskim w latach 1596-1839, [w:] Bielsk Podlaski. Studia i materiały do dziejów miasta, red. Z. Romaniuk, Bielsk Podlaski 1999.

Mazuruk K., Stanowiska archeologiczne Bielska Podlaskiego na tle historiografii, „Białoruskie Zeszyty Historyczne”, 21, 2004.

Mironowicz A., Podlaskie ośrodki i organizacje prawosławne w XVI i XVII wieku, Białystok 1991.

Misiuk Z., Badania archeologiczne w Bielsku Podlaskim na ul. Poniatowskiego 14 przeprowadzone we wrześniu 2003 r., „Białoruskie Zeszyty Historyczne”, 23, 2005.

Ochmański J., Dawna Litwa. Studia historyczne, Olsztyn 1986.

Pawlata L., Badania archeologiczne na starym mieście w Bielsku Podlaskim na tle wyników dotychczasowych badań, „Biuletyn Konserwatorski Województwa Podlaskiego”, 21, 2015 .

Pietkiewicz K., Itinerarium króla Aleksandra Jagiellończyka 1492-1506, Warszawa 2016.

Polechow S., Itinerarium wielkiego księcia litewskiego Witolda: 4/5 sierpnia 1392 - 27 października 1430, „Rocznik Lituanistyczny”, 5, 2019.

Sierba M., Bielsk Podlaski, [w:] Atlas historyczny Polski. Województwo podlaskie w drugiej połowie XVI w., red. M. Gochna, B. Szady, Warszawa 2021 [w druku].

Szymański W., Komunikat o wynikach sondażowych badań grodzisk w Bielsku Podlaskim i we Wnorach-Wypychach, „Rocznik Białostocki”, 13, 1976.

Wrede M., Itinerarium króla Stefana Batorego 1576-1586, Warszawa 2010.

Wrede M., Itinerarium króla Zygmunta III 1587-1632, Warszawa 2019.

Zieleniewski J., Powstanie i rozwój układu przestrzennego Bielska Podlaskiego w XIVXVIII wieku, „Studia Podlaskie”, 1, 1990.

Zieleniewski J., Średniowieczny zespół osadniczo-obronny w Bielsku Podlaskim. Siedziba namiestników bielskich w panoramie miasta z pierwszej połowy XVI w., [w:] Europa Orientalis. Polska i jej wschodni sąsiedzi od średniowiecza po współczesność. Studia $i$ materiały ofiarowane Profesorowi Stanisławowi Alexandrowiczowi w 65 rocznice urodzin, red. Z. Karpus, T. Kempa, D. Michaluk, Toruń 1996.

Zieleniewski J., Bielsk Podlaski - topografia historyczna w XII-XVIII w., Białystok 19801981, praca magisterska pod kier. prof. S. Alexandrowicza.

Покровский Ф.В., Археологическая карта Гробненской губернии, Вильна 1896. 


\title{
The Volok Reform of Bielsk made by Stanisław Dziewiałtowski Skoczek in 1560
}

\begin{abstract}
Summary
The article discusses the question of the Volok Reform carried out in Bielsk (today Bielsk Podlaski) in Podlasie in 1560 by Stanisław Dziewiałtowski Skoczek. It was not the last undertaking of this type, as in 1563 the reform was made again by Andrzej Dybowski. The Volok Reform from 1560 has not been preserved in the original register, but in the form of an abbreviated, anonymous note. The source edition is included in the second part of the article. It is one of the few preserved sources that allows to recreate the urban layout of Bielsk in the $16^{\text {th }}$ century. The article supplements the plan of Bielsk in 1563, together with a commentary that will be published as part of the Historical Atlas of Poland.

Michał Sierba - doktor historii, muzealnik i nauczyciel badający dzieje Podlasia w epoce nowożytnej. Autor m.in. książki Radziwiłłowskie dobra Orla (1585-1695), edycji źródłowej Lustracja województwa podlaskiego w 1602 r. i kilkudziesięciu artykułów naukowych na temat historii Podlasia.

e-mail:michal_sierba@wp.pl
\end{abstract}

